\author{
MEDICINAL PLANT COMMUNICATIONS \\ (C) / ISSN 07177917 / www.mpc.ms-editions.cl \\ https://doi.org/10.37360/mpc.21.4.1.02
}

\title{
Review \\ Antibacterial potential of essential oils from medicinal plants for food preservation: a review
}

\author{
[Potencial antibacteriano de los aceites esenciales de plantas medicinales \\ para la conservación de alimentos: una revision]
}

\begin{abstract}
Camila Frederico, Suelen Sorato Mendes, Lidaiane Mariah Silva dos Santos Franciscato, Stéfany Cordeiro de Souza, Kátia Castilho de Oliveira, Maria Graciela Iecher Faria, Zilda Cristiani Gazim \& Suelen Pereira Ruiz*
\end{abstract}

\author{
Programa de Pós-Graduação em Biotecnologia Aplicada à Agricultura, \\ Universidade Paranaense, Umuarama, Brazil \\ *Correspondence to: suelenruiz@prof.unipar.br
}

\begin{abstract}
Essential oils, also called volatile or ethereal oils, are compounds naturally present in plants. Several medicinal plants are sources of these essential oils extraction, besides different secondary metabolites that are produced, such as terpenoids, alcoholic compounds, aldehydes, ketone bodies and phenols. The essential oils usage as substitutes for synthetic preservatives in food has been gaining space in research due to the interest of the population in consuming healthier products. Moreover, the industry seeks to attend the necessities of the consumers to produce foods with less synthetic additives, but ensuring the preservation of organoleptic characteristics and shelf life. This review aims to present the antibacterial activity of essential oils from medicinal plants and its use as a food preservative.
\end{abstract}

Keywords: Food pathogens; Preservatives; Foodborne diseases; Volatile oils.

Resumen: Los aceites esenciales, también llamados aceites volátiles o etéreos, son compuestos presentes de forma natural en las plantas. Varias plantas medicinales son fuente de extracción de estos aceites esenciales, además de diferentes metabolitos secundarios que se producen, como terpenoides, compuestos alcohólicos, aldehídos, cuerpos cetónicos y fenoles. El uso de aceites esenciales como sustitutos de conservantes sintéticos en los alimentos ha ido ganando espacio en la investigación debido al interés de la población por consumir productos más saludables. Además, la industria busca satisfacer las necesidades de los consumidores de producir alimentos con menos aditivos artificiales, pero asegurando la preservación de las características organolépticas y la vida útil. Esta revisión tiene como objetivo presentar la actividad antibacteriana de los aceites esenciales de plantas medicinales y su uso como conservante de alimentos.

Palabras clave: Patógenos alimentarios; Conservantes; Enfermedades transmitidas por alimentos; Aceites volátiles.

Received: May 10, 2021

Accepted: May 26, 2021

Published online: May 30, 2021

This article must be cited as: Frederico C, Mendes SS, Franciscato LMSS, de Souza SC, de Oliveira KC, Faria MGI, Gazim ZC, Ruiz SP. 2020. Antibacterial potential of essential oils from medicinal plants for food preservation: a mini-review. Med Plant Commun 4 (1): 14 - 22. 


\section{INTRODUCTION}

Pathogenic and spoilage microorganisms are naturally present in the environment and can contaminate food at different stages of the production chain, for example, during harvesting, slaughter, processing and/or packaging (Hatab et al., 2016). World food losses can reach $40 \%$ a year, due to numerous factors, including spoilage caused by microorganisms (Gustavsson et al., 2011). Microbial spoilage can be caused by bacteria, molds and yeasts (Lianou et al., 2016), as it uses available nutrients and produces metabolites, which largely affect the sensory and nutritional characteristics of foods (Parlapani et al., 2017).

Contaminant pathogenic microorganisms in food processing can produce toxins that cause harmful effects on human health (Chen et al., 2020). Foods of animal origin were reported as the main carriers of food pathogens, being: eggs, meat by-products, pork, poultry, fish, milk, dairy products, beef and shellfish (EFSA, 2016). The principal associated bacteria are Bacillus cereus, Campylobacter jejuni, Clostridium botulinum, Clostridium perfringens, Cronobacter sakazakii, Escherichia coli, Listeria monocytogenes, Salmonella spp., Shigella spp. and Staphylococcus aureus (Bintsis, 2017), which can cause foodborne illness.

Foodborne illnesses caused through the contaminated food consumption by microorganisms is a challenge to food safety and public health. Every year, around 600 million people in the world sicken and 420.000 die from ingesting contaminated food, mainly by bacteria (FAO, 2019). These diseases undermine socioeconomic development, burdening health systems, as well as the world economy and trade (FAO, 2019). Estimates indicate that the impact of unsafe food generates productivity losses of around US\$95 billion per year in low- and middle-income economies (FAO, 2019).

Antibiotic resistance within food production is a concern for public health, as its indiscriminate use in treatment of human and animal health has become an important influence on the emergence and persistence of resistant strains. According to the US Centers for Disease Control and Prevention, approximately 2 million people are infected with multidrug-resistant (MDR) bacteria annually, averaging 23.000 deaths (Cheng et al., 2019). Because of these factors, the use of natural compounds obtained from aromatic and medicinal plants has become an alternative to control food pathogens, and can be used as preservatives, hence ensuring food quality (Gebreyes et al., 2017).

Consistent with the National Health Surveillance Agency, preservatives can be considered as additives, that is, any and all ingredients intentionally added to foods without the purpose of nourishing, with the objective of modifying the physical, chemical, biological or sensory characteristics, during manufacture, processing, preparation, treatment, packaging, conditioning and storage (Brasil, 1997). Synthetic antimicrobial preservatives are used in order to extend the foods shelf life, but it can cause toxic effects on individuals exposed through food consumption, depending on the amount ingested and the susceptibility of the human body. In indiscriminate amounts, preservatives can cause the following health problems: benzoic acid (asthma), sorbic acid (hives, asthma and allergy), sulfur dioxide (toxicological effects and respiratory problems), sulfites (allergies, hypotension, nausea, gastric irritation, hyperactivity, diarrhea, asthma attacks and urticaria), nitrites and nitrates generates methemoglobinemia, which, in addition to being carcinogenic, can cause increased blood pressure, heart disease, vasodilator action, headache and gastrointestinal discomfort (Conte, 2016; Bensid et al., 2020).

Considering the occurrence of antimicrobial resistance and possible diseases caused by the use of synthetic preservatives, studies with the addition of natural substances, such as essential oils in foods have been developed. Essential oils, also called volatile or ethereal oils, are compounds naturally present in plants and have functions related to its defense mechanisms. The essential oil content in the plant can be associated with several factors, for example: temperature, luminosity, seasonality, plant development stage, harvest time and plant nutrition. Essential oil are oily aromatic liquids, characterized by intensive flavor and smell, and can be obtained from plant material, such as flowers, shoots, seeds, leaves, branches, bark, wood, fruits and roots (Morais, 2009; Dhifi et al., 2016). The use of essential oils as a substitute for synthetic preservatives in food is of great interest to the industry, which seeks to attend the needs of its consumers, aiming to produce food with fewer artificial additives, but ensuring the maintenance of the sensory characteristics and safety of the product. (Tajkarimi et al., 2010). This review article is focused on the potential antibacterial activity of essential oils from medicinal plants and its utilization as food 
preservatives. Aspects, such as chemical composition, antimicrobial activities, as current application of essential oil from medicinal plants in food matrices, have been discussed.

\section{METHODOLOGY}

In the present study, the narrative bibliographical review was carried out using the databases Science Direct, Scopus and Scielo platforms, as scientific databases. The keywords used as descriptors were: "essential oils", "medicinal plants essential oil", "food preservative", "antibacterial", as a search strategy. Articles published during the period from 2018 to 2021 were selected. Articles from previous years were maintained in the base of the article, once the information reported was considered of importance for the general discussion.

\section{Chemical composition and antibacterial activity of essential oils from medicinal plants}

Essential oils are constituted by a complex mixture of polar and non-polar substances (Raut \& Karuppayil, 2014), which different secondary metabolites can be present as terpenes (monoterpenes and sesquiterpenes), aromatic compounds (aldehyde, alcohol, phenol, methoxy derivative, etc.), and terpenoids (isoprenoids) (Bakkali et al., 2008). Essential oils have exhibited promising antimicrobial action against several microbial species (RibeiroSantos et al., 2018). Table No. 1 compiles the essential oils of some medicinal plants species, major chemical compounds and the minimum inhibitory concentration (MIC) against the principal pathogenic bacteria of interest in foods. The chemical compounds that constitute essential oils can vary according to the plant species and the plant part used for extraction, such as branches, leaves, flowers, seeds, rhizomes and fruits (Edris, 2007). Furthermore, the chemical composition may vary depending on climatic conditions, harvest time, geographic region, cultivation method, soil and maturation stage (Dhifi et al., 2016; Ribeiro-Santos et al., 2018; Li et al., 2020), and all these factors can influence the antibacterial activity.

The action mechanism of the antibacterial activity of essential oils has not yet been completely elucidated (Calo et al., 2015). Gram-positive bacteria are generally more susceptible to essential oils than Gram-negative bacteria (Nazzaro et al., 2013), because the complexity of the its cell wall constitution, such as the presence of lipopolysaccharide, that hinders the essential oil penetration into the cell (Nazzaro et al., 2013). Since it is constituent of several biomolecules, the antimicrobial activity of essential oils cannot be confirmed based on a single mode of action (Bajpai et al., 2012). The action can be attributed to the ability to penetrate the bacterial cell membrane and inhibit its functioning properties (Bajpai et al., 2012).

The antibacterial action of essential oils may be linked to the major phenolic compounds presence, such as thymol, carvacrol and eugenol, however, studies have demonstrated that other compounds present in smaller amounts that act in synergism, altering the permeability of the bacterial cell membrane, causes death (Rattanachaikunsopon \& Phumkhachorn, 2010; Adelakun et al., 2016). The oregano essential oil, which has carvacrol and $p$-cymene, as major, can cause irreversible damage to the cell membrane of MRSA S. aureus, inhibit the tricarboxylic acid cycle pathway and its main enzymes, as well as inhibit the expression of the pvl gene; in addition, the major compound carvacrol can form chimera with DNA (Cui et al., 2019). Ginger essential oil, which is mainly zingiberene and $\alpha$ curcumene, can inhibit the expression of some genes related to energy metabolism, tricarboxylic acid cycle, cell membrane-related proteins and DNA metabolism in E. coli and S. aureus (Wang et al., 2020).

Studies have related the combined action of the compounds carvacrol and thymol in the disintegration of the outer membrane present in the wall of Gram-negative bacteria, releasing lipopolysaccharides and increasing the permeability of the cytoplasmic membrane to ATP (Helander et al., 1998; Lambert et al., 2001; Burt, 2004). Eugenol promotes cell wall degradation and cell lysis (Thoroski et al., 1989). P-cymene, the carvacrol precursor, has high affinity for the membranes of microorganisms, due to the benzene ring in the chemical structure, which can disturb the cell membrane potential and cause swelling of the cytoplasmic membrane (Ultee et al., 2002). Terpinen-4-ol promotes inhibition of oxidative respiration, inducing membrane deformation, causing changes in membrane permeability (Cox et al., 2000). 
Table No. 1

Chemical composition and minimum inhibitory concentration (MIC) of essential oils from some medicinal plants species in vitro on pathogenic bacteria of interest in food

\begin{tabular}{|c|c|c|c|}
\hline Plant & Major compounds & Bacterium and MIC $(\mathrm{mg} / \mathrm{mL})$ & Reference \\
\hline Origanum vulgare & $\begin{array}{l}\text { Carvacrol }(64,86 \%) \\
\rho \text {-Cymene }(8.354 \%)\end{array}$ & $\begin{array}{l}\text { Staphylococcus aureus - MRSA } \\
(0.4)\end{array}$ & Cui et al., 2019 \\
\hline Cinnamomum camphora (Linn.) & $\begin{array}{l}\text { Linalool }(26.6 \%) \\
\text { eucalyptol }(16.8 \%) \\
\alpha \text {-terpineol }(8.7 \%) \text {, } \\
\text { isoborneol }(8.1 \%) \\
\beta \text {-phellandrene }(5.1 \%) \\
\text { camphor }(5.0 \%) \\
\end{array}$ & $\begin{array}{l}\text { Staphylococcus aureus (1.6) } \\
\text { Bacillus subtilis }(1.6) \\
\text { Enterococcus faecalis }(1.6) \\
\text { Escherichia coli }(3.2) \\
\text { Salmonella gallinarum }(1.6)\end{array}$ & Chen et al., 2020 \\
\hline Psidium cattleianum (leaves) & $\begin{array}{l}\beta \text {-caryophyllene }(14.7 \%) \\
1,8 \text {-cineole }(11.7 \%) \\
\gamma \text {-muurolene }(5.6 \%)\end{array}$ & $\begin{array}{l}\text { Bacillus cereus }(1.40) \\
\text { Pseudomonas aeruginosa }(1.40) \\
\text { Staphylococcus aureus }(2.10) \\
\text { Salmonella enterica }(5.62)\end{array}$ & Salvoldi et al., 2020 \\
\hline Myrcianthes pungens (leaves) & $\begin{array}{l}\beta \text {-caryophyllene }(11.7 \%) \\
1,8 \text {-cineole }(10.1 \%)\end{array}$ & $\begin{array}{l}\text { Staphylococcus aureus }(0.078) \\
\text { Bacillus cereus }(0.42)\end{array}$ & De Jesus et al., 2021 \\
\hline Baccharis coridifolia & $\begin{array}{l}\text { Germacrene-D (23.7\%), } \\
\text { bicyclogermacrene }(17.1 \%) \\
\text { (E)-caryophyllene }(8.4 \%)\end{array}$ & $\begin{array}{l}\text { Pseudomonas aeruginosa }(0.51) \\
\text { Staphylococcus aureus }(0,128)\end{array}$ & Freitas et al., 2020 \\
\hline Cinnamom cassia & E-cinnamaldehyde (76.54\%) & Listeria monocytogenes $(0.1)$ & Somrani et al., 2020 \\
\hline Zingiber officinale & $\begin{array}{l}\text { Zingiberene }(35.65 \%) \\
\alpha \text {-Curcumene }(12.04 \%)\end{array}$ & Staphylococcus aureus (1.0) & Wang et al., 2020 \\
\hline Rosmarinus officinalis $\mathrm{L}$. & $\begin{array}{l}1,8 \text {-cineole }(17.16 \%) \\
\alpha \text {-pinene }(16.95 \%)\end{array}$ & Staphylococcus aureus (0.06) & Mohammed et al., 2020 \\
\hline Litsea cubeba & $\begin{array}{l}\beta \text {-Citral }(39.25 \%) \\
\alpha \text {-Citral }(30.89 \%) \\
\text { Limonene }(8.28 \%)\end{array}$ & Escherichia coli $\mathrm{O} 157: \mathrm{H} 7(0.5)$ & Dai et al., 2021 \\
\hline Laurus nobilis L. (leaves) & $\begin{array}{l}1.8 \text {-cineol }(41.1 \%) \\
\text { sabinene }(6.96 \%) \\
\alpha \text {-pinene }(5.94 \%) \\
\text { humulene epoxide II }(5.73 \%) \\
\alpha \text {-terpinenyl acetate }(5.72 \%)\end{array}$ & $\begin{array}{l}\text { Escherichia coli } \mathrm{O} 157: \mathrm{H} 7(0.75) \\
\text { Staphylococcus aureus }(0.75) \\
\text { Listeria monocytogenes }(0.37) \\
\text { Bacillus cereus }(0.75)\end{array}$ & Tomar et al., 2020 \\
\hline Syzygium aromaticum, $\mathrm{L}$. & $\begin{array}{l}\text { Eugenol }(56.06 \%) \\
\text { caryophyllene }(39.63 \%) \\
\alpha \text {-caryophyllene }(4.31 \%)\end{array}$ & $\begin{array}{l}\text { Staphylococcus aureus }(0.30) \\
\text { Escherichia coli }(0.30) \\
\text { Listeria monocytogenes }(0.30) \\
\text { Salmonella typhimurium }(0.30) \\
\end{array}$ & Radünz et al., 2019 \\
\hline Satureja khuzestanica & $\begin{array}{l}\text { Carvacrol }(87.16 \%) \\
p \text {-cymene }(6.39 \%)\end{array}$ & \begin{tabular}{|l} 
Escherichia coli $(0.25)$ \\
Staphylococcus aureus $(0.25)$ \\
Salmonella enterica $(0.25)$
\end{tabular} & Mazarei \& Rafati, 2019 \\
\hline
\end{tabular}

\section{Applications of essential oils from medicinal plants in food}

Essential oils are of growing interest due to the population's demands from consumers for natural foods. Several studies with the application of essential oils from medicinal plants are reported in Table No. 2, aiming at the control of pathogenic bacteria in different food matrices. Litsea cubeba essential oil was tested in bitter gourd, cucumber, carrots and spinach juices at $4{ }^{\circ} \mathrm{C}$ (common storage temperature for fresh juices) and in MIC concentration $(0.5$ $\mathrm{mg} / \mathrm{mL}$ ), the viable count of E. coli O157:H7 in four samples decreased above 99\% after 4 days storage (Dai et al., 2021). Radünz et al. (2019), showed that clove essential oil inhibited the growth of $S$. aureus in burger-like meat more efficiently than the preservative nitrite. Šojić et al. (2018), showed that the addition of $0.1 \mu \mathrm{L} / \mathrm{g}$ of Salvia officinalis essential oil in fresh pork sausage contributed to a reduction from $7.66 \mathrm{log} \mathrm{cfu} / \mathrm{g}$ (control) to $7.0 \mathrm{log} / \mathrm{cfu} \mathrm{g}$ of total mesophilic aerobic count after 8 days storage. Ksouda et al. (2019), reported that the presence of $3 \%$ of Pimpinella saxifraga essential oil in cheese coating reduced the proliferation of mesophilic bacteria from 5.44 to $4.03 \log$ CFU/g at day 7 of chilled storage. Sahin \& Kilic (2021), evaluated the antimicrobial capacity of some 
essential oils, obtaining more effective results through the Thymus vulgaris essential oil, which presented zones of inhibition of $49.27 \pm 7.26 \mathrm{~mm}$ against $S$. aureus, $44.13 \pm 4.16 \mathrm{~mm}$ against $L$. monocytogenes, $39.55 \pm 0.52 \mathrm{~mm}$ against $E$. coli and $38.09 \pm 4.15 \mathrm{~mm}$ against $M$. luteus. The chromatography performed by the authors presented thymol, carvacrol, caryophyllene, 1,8-cineole, 2-acetyl-4,5-dimethylphenol and $\gamma$-terpinene in the composition of $T$. vulgaris.

An important factor in the application of a substance in a food system is the medium homogeneity used in preliminary in vitro tests, which in liquid or in gel culture medium can be more effective; on the other hand, once applied to foods, the effectiveness will depend on the matrix composition, which can be complex or heterogeneous (Weiss et al., 2015). Because of the possibility of interacting with food components, high concentrations may be necessary to achieve the same efficacy in comparison to the in vitro tests (Aloui \& Khwaldia, 2016). Therefore, detailed studies of the antimicrobial properties of essential oils, such as MIC, action mode and target microorganism, in addition to the interaction with food components, are necessary for application as biopreservatives to control microorganisms in food systems (Hyldgaard et al., 2012).

Factors inherent to foods also influence the antimicrobial activity of essential oils after applied to food matrices, such as chemical composition, $\mathrm{pH}$, water activity, temperature and storage atmosphere. Low $\mathrm{pH}$ values can contribute to increase the solubility and stability of the essential oils (Burt, 2004). High concentration of proteins or fats in food composition can provide a protective layer around the microorganism or absorb the antimicrobial substance, consequently, reducing its concentration and effectiveness in aqueous medium (Tyagi et al., 2012; Perricone et al., 2015). Thyme and cinnamon essential oils were more effective against Salmonella in hydrated tahini (water activity of 0.96 ) than non-hydrated (water activity of 0.25 ), as the hydration provided dilution and reduced the fat content available in the product (Al-Nabulsi et al., 2020).

The combination of essential oils from different plant species can increase the spectrum of antimicrobial action through synergism. Diniz-Silva et al. (2019), showed that essential oils from Origanum vulgare L. $(0.03 \mu \mathrm{L} / \mathrm{g})$ and Rosmarinus officinalis $L$. $(1.32 \mu \mathrm{L} / \mathrm{g})$ had a synergistic effect against $E$. coli $\mathrm{O} 157: \mathrm{H} 7$ in fresh cheese. The terpene content decreased during the fresh cheese storage, and the non-detection of y-terpinene and carvacrol after 3 days of storage may be related to its solubility and volatility, as well as to its ability to react with proteins and fat (DinizSilva et al., 2019).

Likewise, the use of essential oils incorporated in polymeric matrices is a well-studied method, which provides good food preservation results. Raeisi et al. (2020), produced nanofiber coatings from isolated soybean protein and gelatin, incorporated with essential oil of Zataria multifora and Cinnamon zeylanicum. The authors reported the biofilm incorporated with $20 \%$ of Z. multifora reduced $100 \%$ the action of S. aureus, B. cereus and L. monocytogenes and the reduction against $E$. coli was $70 \%$, and $63 \%$ for $S$. typhimurium.

\section{Challenges and perspectives for essential oils application in food}

As a natural origin compound, essential oils have become an attraction for population and industries, in the search for alternatives to develop healthier and quality products (Tajkarimi et al., 2010). Nevertheless, despite the effectiveness of the antibacterial potential of essential oils for application in food matrix, detailed studies are necessary to promote the desired antimicrobial effect, without changing the sensory characteristics of the food, since in many cases the required inhibitory concentration is greater than the determined in vitro assays (Bhavaniramya et al., 2019; Falleh et al., 2020), thus impairing the final flavor of the product.

In addition to sensory alterations due to its intense flavor, essential oils can be affected by stability at high temperatures, light and oxygen, consequently, limiting the use as natural preservatives (Zhu et al., 2021). Radunz et al. (2020), studied Thymus vulgaris essential oil microencapsulated in casein-maltodextrin capsules produced by spray-drying and found that encapsulated was more effective than non-encapsulated in preserving hamburger-like products against E. coli. They obtained an antimicrobial effect up to 14 days of storage due to the slow release of volatile compounds, which were protected by encapsulation, and the results were similar to the synthetic additive nitrite (Radünz et al., 2020). Froiio et al. (2019), mentioned that the essential oils incorporation in polymeric matrix 
is a manner to protect it from degradation, make it soluble to be incorporated in aqueous environment, camouflage its strong aroma and avoid its interaction with others food components. However, this method still needs economic and process adjustments to be feasible on industrial scales. Therefore, it is noted that as effective as essential oils are, it is still necessary to establish a methodology that enables its usage in industry.

Table No. 2

Application of essential oils from medicinal plants as antibacterial in different food matrix

\begin{tabular}{|c|c|c|c|c|}
\hline Plant & Major compounds & Food matrix & Microorganism & Reference \\
\hline Litsea cubeba & $\begin{array}{l}\beta \text {-Citral }(39.25 \%) \\
\alpha-\text { Citral }(30.89 \%) \\
\text { Limonene }(8.28 \%)\end{array}$ & Vegetable juices & E. coli $\mathrm{O} 157: \mathrm{H} 7$ & Dai et al., 2021 \\
\hline Syzygium aromaticum $\mathrm{L}$. & $\begin{array}{l}\text { Eugenol }(56.06 \%), \\
\text { Caryophyllene }(39.63 \%) \\
\alpha \text {-caryophyllene }(4.31 \%)\end{array}$ & burger-like meat & S. aureus & Radünz et al., 2019 \\
\hline Cinnamon & - & Tahini & Salmonella spp. & Al-Nabulsi et al., 2020 \\
\hline Salvia officinalis L. & $\begin{array}{l}\text { Epirosmanol }(26.25 \%) \text {, } \\
\text { Viridiflorol }(18.42 \%) \\
\text { Camphor }(12.74 \%)\end{array}$ & $\begin{array}{l}\text { Fresh pork } \\
\text { sausage }\end{array}$ & $\begin{array}{l}\text { Total mesophilic } \\
\text { aerobic count }\end{array}$ & Šojić et al., 2018 \\
\hline Zingiber officinale & $\begin{array}{l}\alpha \text {-zingiberene }(24.96 \%) \\
\beta \text {-sesquiphellandrene }(12.74 \%)\end{array}$ & $\begin{array}{l}\text { Coating emulsão } \\
\text { in chicken breast } \\
\text { fillets }\end{array}$ & $\begin{array}{l}\text { Psychrophilic } \\
\text { bacteria }\end{array}$ & Noori et al., 2018 \\
\hline Pimpinella saxifraga & $\begin{array}{l}\text { Anethole }(59.47 \%) \\
\text { Pseudoisoeugenol }(20.15 \%)\end{array}$ & Sicilian cheese & $\begin{array}{l}\text { Mesophilic } \\
\text { bacteria }\end{array}$ & Ksouda et al., 2019 \\
\hline Pimpinella anisum & $\begin{array}{l}\text { Anethole }(80.84 \%) \\
\text { Piperitenone oxide }(5.76 \%) \\
p \text {-Allylanisole }(2.9 \%) \\
\text { Acetisoeugenol }(2.05 \%) \\
\text { trans-Caryophyllene }(2.05 \%)\end{array}$ & Minced beef & Pseudomonas spp. & Khanjari et al., 2018 \\
\hline $\begin{array}{l}\text { Origanum vulgare } L . \\
\text { Rosmarinus officinalis } L .\end{array}$ & $\begin{array}{l}\text { Origanum: } \\
\text { Thymol } \\
\rho \text {-cymene } \\
\text { Carvacrol } \\
\gamma \text {-terpinene } \\
\text { Rosmarinus: } \\
\text { Eucalyptol } \\
\text { Camphor } \\
\alpha \text {-pinene } \\
\text { Caryophyllene } \\
\text { Camphene }\end{array}$ & Fresh cheese & $\begin{array}{l}\text { Escherichia coli } \\
\text { O157:H7 }\end{array}$ & Diniz-Silva et al., 2019 \\
\hline
\end{tabular}

\section{CONCLUSION}

Essential oils from medicinal plants exhibit potential against pathogenic and spoilage bacteria of interest in foods. Essential oils are promising alternatives for replacing synthetic preservatives used in the food industry. Overall, essential oils application in food is a challenge that requires further studies and improvement of techniques so barriers, such as flavor alterations and substance oxidation, making its usage and acceptability viable.

\section{REFERENCES}

Adelakun OE, Oyelade OJ, Olanipekun BF. 2016. Use of essential oils in food preservation. In: Preedy VR. Essential oils in food preservation, flavor, and safety. Academic Press is an imprint of Elsevier. https://doi.org/10.1016/b978-0-12-416641-7.00007-9

Al-Nabulsi AA, Osaili TM., Olaimat AN, Almasri WE, Ayyash M, Al-Holy MA, Jaradat ZW, Obaid RS, Holley RA. 2020. Inactivation of Salmonella spp. in tahini using plant essential oil extracts. Food Microbiol 86: 1-9. https://doi.org/10.1016/j.fm.2019.103338

Aloui H, Khwaldia K. 2016. Natural antimicrobial edible coatings for microbial safety and food quality enhancement. 
Compr Rev Food Sci Food Saf 16: 1080-1103. https://doi.org/10.1111/1541-4337.12226

Bajpai VK, Baek KH, Kang SC. 2012. Control of Salmonella in foods by using essential oils: a review. Food Res Int 45: 722-734. https://doi.org/10.1016/j.foodres.2011.04.052

Bakkali F, Averbeck S, Averbeck D, Idaomar M. 2008. Biological effects of essential oils e a review. Food Chem Toxicol 46: 446-475. https://doi.org/10.1016/j.fct.2007.09.106

Bensid A, El Abed N, Houicher A, Regenstein JM, Özogul F. 2020. Antioxidant and antimicrobial preservatives: Properties, mechanism of action and applications in food - a review. Crit Rev Food Sci Nutr: 1-15. https://doi.org/10.1080/10408398.2020.1862046

Bhavaniramya S, Vishnupriya S, Al-Aboody MS, Vijayakumar R, Baskaran D. 2019. Role of essential oils in food safety: Antimicrobial and antioxidant applications. Grain Oil Sci Technol 2: 49-55.

https://doi.org/10.1016/j.gaost.2019.03.001

Bintsis T. 2017. Foodborne pathogens. AIMS Microbiol 3: 529-563. https://doi.org/10.3934/microbiol.2017.3.529

Brasil. 1997. Ministério da Saúde. Agência Nacional de Vigilância Sanitária. Legislação. Aprova o Regulamento Técnico: Aditivos Alimentares - definições, classificação e emprego. http://www.anvisa.gov.br

Burt S. 2004. Essential oils: their antibacterial properties and potential applications in foods a review. Int J Food Microbiol 94: 223-253. https://doi.org/10.1016/j.ijfoodmicro.2004.03.022

Calo RJ, Crandall PG, Corliss AO, Steven CR. 2015. Essential oils as antimicrobials in food systems e A review. Food Control 54: 111-119. https://doi.org/10.1016/j.foodcont.2014.12.040

Chen J, Tang C, Zhang R, Ye S, Zhao Z, Huang Y, Xu X, Lan W, Yang D. 2020. Metabolomics analysis to evaluate the antibacterial activity of the essential oil from the leaves of Cinnamomum camphora (Linn.) Presl. J Ethnopharmacol 253: 1-10. https://doi.org/10.1016/j.jep.2020.112652

Cheng D, Ngo HH, Guo W, Chang SW, Nguyen DD, Liu Y, Wei Q, Wei D. 2019. A critical review on antibiotics and hormones in swine wastewater: Water pollution problems and control approaches. J Hazard Mater 387: 1-12. https://doi.org/10.1016/j.jhazmat.2019.121682

Conte F A. 2016. Efeitos do consumo de aditivos químicos alimentares na saúde humana. Rev Espaço Acad 16: 6981.

Cox SD, Mann JL, Bell HC, Gustafson JE, Warmingtn JR, Wyllic SG. 2000. The mode of antimicrobial action of the essential oils of Melaleuca alternifolia (tea tree oil). J Appl Microbiol 88: 170-175. https://doi.org/10.1046/j.1365-2672.2000.00943.x

Cui H, Zhang C, Li C, Lin L. 2019. Antibacterial mechanism of oregano essential oil. Ind Crops Prod 139: 1-9. https://doi.org/10.1016/j.indcrop.2019.111498

Dai J, Li C, Cui H, Lin L. 2021. Unraveling the anti-bacterial mechanism of Litsea cubeba essential oil against E. coli O157:H7 and its application in vegetable juices. Int J Food Microbiol 338: 1-11.

https://doi.org/10.1016/j.ijfoodmicro.2020.108989

Dhifi W, Bellili S, Jazi S, Bahloul N, Mnif W. 2016. Essential oils' chemical characterization and investigation of some biological activities: A Critical Review. Medicines 3: 1-16. https://doi.org/10.3390/medicines3040025

Diniz-Silva HT, Souza JB, Guedes JS, Ramos RCREQ, Madruga MS, Tavares JF, Souza EL, Magnani M. 2019. A synergistic mixture of Origanum vulgare L. and Rosmarinus officinalis L. essential oils to preserve overall quality and control Escherichia coli O157:H7 in fresh cheese during storage. LWT - Food Sci Technol 112: 1-9.

https://doi.org/10.1016/j.lwt.2019.01.039

Edris AE. 2007. Pharmaceutical and therapeutic potentials of essential oils and their individual volatile constituents: a review. Phytother Res 21: 308-323. https://doi.org/10.1002/ptr.2072

EFSA (European Food Safety Authority). 2016. The European Union summary report on trends and sources of zoonoses, zoonotic agents and food-borne outbreaks in 2015. EFSA J 14: 4634-4865. https://doi.org/10.2903/j.efsa.2015.3991

Falleh H, Jemaa MB, Saada M, Ksouri R. 2020. Essential oils: a promising eco-friendly food preservative. Food Chem 330: 1-40. https://doi.org/10.1016/j.foodchem.2020.127268

FAO (Food and Agriculture Organization). 2019. Food safety, everyone's business. A Guide to World Food Safety Day 2019. FAO, Rome, Italy.

https://www.paho.org/hq/index.php?option=com_docman\&view=download\&slug=world-foodsafety-day-2019-guide $\&$ Itemid $=270 \&$ lang $=$ en

Freitas PR, Araújo ACJ, Barbosa CRS, Muniz DF, Rocha JE, Neto JBA, Silva MMC, Pereira RLS, Silva LE, Amaral W, Deschamps C, Tintino SR, Filho JR, Coutinho HDM. 2020. Characterization and antibacterial activity of the 
essential oil obtained from the leaves of Baccharis coridifolia DC against multiresistant strains. Microb Pathog 145: 1-5. https://doi.org/10.1016/j.micpath.2020.104223

Froiio F, Mosaddik A, Morshed MT, Paolino D, Fessi H, Elaissari A. 2019. Edible polymers for essential oils encapsulation: application in food preservation. Ind Eng Chem Res 58: 20932-20945.

https://doi.org/10.1021/acs.iecr.9b02418

Gebreyes WA, Wittum T, Habing G, Alali W, Usui M, Suzuki S. 2017. Spread of antibiotic resistance in food animal production systems. In: Dodd C, Aldsworth T, Stein RA, Cliver DO, Riemann HP. (Ed.). Foodborne Diseases. Academic Press, Cambridge, UK. https://doi.org/10.1016/b978-0-12-385007-2.00004-8

Gustavsson J, Cederberg C, Sonesson U, Otterdijk R, Maybeck A. 2011. Global food losses and food waste: extent, causes, and prevention. FAO, Düsseldorf, Germany. http://www.fao.org/3/mb060e/mb060e.pdf

Hatab S, Athanasio R, Holley R, Rodas-Gonzalez A, Narvaez-Bravo C. 2016. Survival and reduction of shiga toxinproducing Escherichia coli in a fresh cold-pressed juice treated with antimicrobial plant extracts. J Food Sci 81: 1987-1995. https://doi.org/10.1111/1750-3841.13382

Helander IM, Alakomi HL, Latva-Kala K, Mattila-Sandholm T, Pol I, Smid EJ, Gorris LGM, Von Wright A. 1998. Characterization of the action of selected essential oil components on gram-negative bacteria. J Agric Food Chem 46: 3590-3595. https://doi.org/10.1021/jf980154m

Hyldgaard M, Mygind T, Meyer RL. 2012. Essential oils in food preservation: mode of action, synergies, and interactions with food matrix components: a review. Front Microbiol 3: 1-24. https://doi.org/10.3389/fmicb.2012.00012

De Jesus RA, Oliveira HLM, Bortolucci WC, Campo CFAA, Faria MGI, Goncalves JE, Colauto NB, Gazim ZC, Linde GA. 2021. Antioxidant and antibacterial activity of Myrcianthes pungens leaf essential oil. Bol Latinoam Caribe Plantas Med Aromat 2: 147-161. https://doi.org/10.37360/blacpma.21.20.2.12

Khanjari A, Bahonar A, Noori N, Siahkalmahaleh MR, Rezaeigolestani M, Asgarian Z, Khanjari K. 2018. In vitro antibacterial activity of Pimpinella anisum essential oil and its influence on microbial, chemical, and sensorial properties of minced beef during refrigerated storage. Food Saf 39: 1-8. https://doi.org/10.1111/jfs.12626

Ksouda G, Sellimi S, Merlier F, Falcimaigne-cordin A, Thomasset B, Nasrio M, Hajjia M. 2019. Composition, antibacterial and antioxidant activities of Pimpinella saxifraga essential oil and application to cheese preservation as coating additive. Food Chem 288: 47-56. https://doi.org/10.1016/j.foodchem.2019.02.103

Lambert RJW, Skandamis PN, Coote P, Nychas GJE. 2001. A study of the minimum inhibitory concentration and mode of action of oregano essential oil, thymol and carvacrol. J Appl Microbiol 91: 453-462. https://doi.org/10.1046/j.1365-2672.2001.01428.x

Li Y, Konga D, Fub Y, Sussmand MR, Wu H. 2020. The effect of developmental and environmental factors on secondary metabolites in medicinal plants. The effect of developmental and environmental factors on secondary metabolites in medicinal plants. Plant Physiol Biochem 148: 80-89.

https://doi.org/10.1016/j.plaphy.2020.01.006

Lianou A, Panagou EZ, Nychas GJE. 2016. Microbiological spoilage of foods and beverages. In Subramaniam P. Ed. The stability and shelf life of food. Woodhead Publishing, Cambridge, UK. https://doi.org/10.1016/b978-0-08-100435-7.00001-0

Mazarei Z, Rafati H. 2019. Nanoemulsification of Satureja kbuzestanica essential oil and pure carvacrol; comparison of physicochemical properties and antimicrobial activity against en con food pathogens. LWT Food Sci Technol 100: 328-334. https://doi.org/10.1016/j.lwt.2018.10.094

Mohammed J, Kashi FJ, Moghaddam AR, Yazdani M. 2020. Antioxidant, cytotoxic and antibacterial activity of Rosmarinus officinalis L. essential oil against bacteria isolated from urinary tract infection. Eur J Integr Med 38: 1-8. https://doi.org/10.1016/j.eujim.2020.101192

Morais LAS. 2009. Influência dos fatores abióticos na composição química dos óleos essenciais. Hortic Bras 27: 40504063.

Nazzaro F, Fratianni F, Martino LD, Coppola R, Feo VD. 2013. Effect of essential oils on pathogenic bacteria. Pharmaceuticals 6: 1451-1474. https://doi.org/10.3390/ph6121451

Noori S, Zeynali F, Almasi H. 2018. Antimicrobial and antioxidant efficiency of nanoemulsion-based edible coating containing ginger (Zingiber officinale) essential oil and its effect on safety and quality attributes of chicken breast fillets. Food Control 84: 312-320. https://doi.org/10.1016/j.foodcont.2017.08.015

Parlapani FF, Mallouchos A, Haroutounian SA, Boziaris IS. 2017. Volatile organic compounds of microbial and nonmicrobial origin produced on model fish substrate un-inoculated and inoculated with gilt-head sea bream 
spoilage bacteria. LWT Food Sci Technol 78: 54-62. https://doi.org/10.1016/j.1wt.2016.12.020

Perricone M, Arace E, Corbo MR, Sinigaglia M, Bevilacqua A. 2015. Bioactivity of essential oils: a review on their interaction with food components: a review. Front Microbiol 6: 1-7. https://doi.org/10.3389/fmicb.2015.00076

Radünz M, Hackbart HC, Camargo TM, Nunes CFP, Barros FAP, Dal Magro J, Filho PJS, Gandra EA, Radünz AL, Zavareze RE. 2020. Antimicrobial potential of spray drying encapsulated thyme (Thymus vulgaris) essential oil on the conservation of hamburger-like meat products. Int J Food Microbiol 330: 1-8. https://doi.org/10.1016/j.ijfoodmicro.2020.108696

Radünz M, Trindade MLM, Camargo TM, Radünz AL, Borges CD, Gandra EA, Helbig E. 2019. Antimicrobial and antioxidant activity of unencapsulated and encapsulated clove (Syzygium aromaticum L.) essential oil. Food Chem 276: 180-186. https://doi.org/10.1016/j.foodchem.2018.09.173

Raeisi M, Mohammadi MA, Coban OE, Ramezani S, Ghorbani M, Tabibiazar M, Khoshbakht R, Norri SM. 2020. Physicochemical and antibacterial efect of soy protein isolate/gelatin electrospun nanofibers incorporated with Zataria multifora and Cinnamon zeylanicum essential oils. J Food Meas Charact 15: 1116-1126. https://doi.org/10.1007/s11694-020-00700-0

Rattanachaikunsopon P, Phumkhachorn P. 2010. Assessment of factors influencing antimicrobial activity of carvacrol and cymene against Vibrio cholerae in food. J Biosci Bioeng 110: 614-619. https://doi.org/10.1016/j.jbiosc.2010.06.010

Raut JS, Karuppayil SM. 2014. A status review on the medicinal properties of essential oils. Ind Crops Prod 62: 250264. https://doi.org/10.1016/j.indcrop.2014.05.055

Ribeiro-Santos R, Andrade M, Sanches-Silva A, Melo NR. 2018. Essential oils for food application: natural substances with established biological activities. Food Bioproc Technol 11: 43-71. https://doi.org/10.1007/s11947-017-1948-6

Sahin S, Kilic O. 2021. Antioxidant and antibacterial activities of essential oils and aromatic waters of some plants grown in the highlands. Int J Agric Environ Food Sci 5: 133-139. https://doi.org/10.31015/jaefs.2021.2.1

Salvoldi TL, Glamoćlija J, Soković M, Gonçalves JE, Ruiz SP, Linde GA, Gazim ZC, Colauto NB. 2020. Antimicrobial activity of essential oil from Psidium cattleianum Afzel. ex Sabine leaves. Bol Latinoam Caribe Plant Med Aromat 19: 614-627. https://doi.org/10.37360/blacpma.20.19.6.44

Sojic B, Pavilic B, Zerovic Z, Tomovic V, Ikonic P, Kocic-Tanachov S, Dzinic N. 2018. The effect of essential oil and extract from sage (Salvia officinalis L.) herbal dust (food industry by-product) on the oxidative and microbiological stability of fresh pork sausages. LWT Food Sci Technol 89: 749-755. https://doi.org/10.1016/j.lwt.2017.11.055

Somrani M, Inglés MC, Debbabi H, Abidi F, Palop A. 2020. Garlic, onion, and cinnamon essential oil anti-biofilms effect against Listeria monocytogenes. Foods 9: 1-12. https://doi.org/10.3390/foods9050567

Tajkarimi M, Ibrahim S, Cliver DO. 2010. Antimicrobial herb and spice compounds in food. Food Control 21: 11991218. https://doi.org/10.1016/j.foodcont.2010.02.003

Thoroski J, Blank G, Biliaderis C. 1989. Eugenol induced inhibition of extracellular enzyme production by Bacillus cereus. J Food Prot 52: 399-403. https://doi.org/10.4315/0362-028x-52.6.399

Tomar O, Akarca G, Gök V, Ramadan MF. 2020. Composition and antibacterial effects of Laurel (Laurus nobilis L.) leaves essential oil. J Essent Oil Bear Plant 23: 414-421. https://doi.org/10.1080/0972060x.2020.1768903

Tyagi AK, Malik A, Gottardi D, Guerzoni ME. 2012. Essential oil vapour and negative air ions: A novel tool for food preservation. Trends Food Sci Technol 2: 99-113. https://doi.org/10.1016/j.tifs.2012.02.004

Ultee A, Bennink MHJ, Moezelaar R. 2002. The phenolic hydroxyl group of carvacrol is essential for action against the food-borne pathogen Bacillus cereus. Appl Environ Microbiol 68: 1561-1568. https://doi.org/10.1128/aem.68.4.1561-1568.2002

Wang X, Shen Y, Thakur K, Han J, Zhang JG, Hu F, Wei ZJ. 2020. Antibacterial activity and mechanism of ginger essential oil against Escherichia coli and Staphylococcus aureus. Molecules 25: 1-17. https://doi.org/10.3390/molecules25173955

Weiss J, Loeffler M, Terjung N. 2015. The antimicrobial paradox: why preservatives lose activity in foods. Curr Opin Food Sci 4: 69-75. https://doi.org/10.1016/j.cofs.2015.05.008

Zhu H, Li C, Cui H, Lin L. 2021. Encapsulation strategies to enhance the antibacterial properties of essential oils in food system. Food Control 123: 107856. https://doi.org/10.1016/j.foodcont.2020.107856 